ARTIGO

\title{
EDUCAÇÃO DOS POVOS DO CAMPO NO BRASIL: COLONIALIDADE/MODERNIDADE E URBANOCENTRISMO
}

\author{
Magno Nunes Farias ${ }^{1 *}$ \\ ORCID: http://orcid.org/0000-0002-9249-1497 \\ Wender Faleiro ${ }^{2 * *}$ \\ ORCID: https://orcid.org/0000-0001-6419-296X
}

\begin{abstract}
RESUMO: As forças da colonialidade e modernidade se constituem a partir da colonização da América, suas bases são intrínsecas ao urbanocentrismo, que se constrói sob a égide da civilidade, pautado nas dicotomias entre o urbano-superior e o rural-inferior. Nesse processo histórico os povos do campo sofreram e sofrem a ferida colonial pela colonialidade do poder, do saber, do ser e da Natureza. Estruturam-se formas de subalternização dos sujeitos camponeses, os deslegitimando de enunciação epistêmica, econômica, cultural e social na constituição do Brasil. Isso reflete na construção da educação escolar brasileira, que ao longo da história esteve sob o critério urbanocêntrico/colonial/moderno, (re) produzindo relações de inferiorização das mulheres e homens do campo, tendo suas marcas desde a constituição da educação colonial até a república atual - o que se denominou aqui de Colonialidade da educação. Nesses percursos existiram e existem movimentos de resistência, como o Movimento de Educação do Campo, caracterizado como fenômeno decolonial insurgente protagonizado pelos povos e movimentos sociais camponeses, e que tem enunciado epistemologias alternativas no enfrentamento e resistência à violência colonial. Coloca-se como emergente o fortalecimento de práticas, conhecimentos e experiências desse projeto decolonial de educação, que tem o potencial de desenvolver novas epistemologias, ontologias e formas de educação institucional e não-institucional.
\end{abstract}

Palavras-chave: colonialidade; urbancentrismo; educação rural; educação do campo; decolonialidade.

\section{EDUCATION OF RURAL PEOPLE IN BRAZIL: COLONIALITY / MODERNITY AND URBANOCENTRISM}

ABSTRACT: The power of coloniality and modernity are constituted by the colonization movements of America, their bases are intrinsic to urbanocentrism, which is built on the aegis of civility, and based on the constructions of dichotomies between urban-superior and rural-inferior. In this historical process the people of the countryside suffered and suffer the colonial wound through the coloniality of power, knowledge, being and Nature. Ways of subordination of countryside's people are structured,

\footnotetext{
${ }^{1}$ Universidade Federal de São Carlos, São Carlos, SP, Brasil.

* Doutorando em Educação pela Universidade Federal de São Carlos (UFSCar), Mestre em Educação pela Universidade Federal de Goiás (UFG), bacharel em Terapia Ocupacional pela Universidade de Brasília (UnB). Integra o Grupo de Pesquisa "Cidadania, Ação Social, Educação e Terapia Ocupacional" (UFSCar).

E-mail: magnonfarias@hotmail.com

${ }^{2}$ Universidade Federal de Goiás, Catalão, GO, Brasil.

** Professor do Programa de Pós-Graduação em Educação da Universidade Federal de Goiás, Catalão. Licenciado e Bacharel em Ciências Biológicas, licenciado em Pedagogia pela Universidade Federal de Uberlândia (UFU); mestre em Ecologia e Conservação de Recursos Naturais e Doutorado em Educação pela UFU. Pós Doutor em Educação pela PUC-GO. Líder Grupo de Pesquisa e Extensão em Ensino de Ciências e Formação de Professores - GEPEEC.

E-mail: wender.faleiro@mail.com
} 
delegitimizing them of epistemic, economic, cultural and social enunciation at the constitution of Brazil. This reflects on construction of Brazilian school education, which has always been under the urban / colonial / modern sieve, (re) producing relationships of inferiority among the rural women and men, having its marks from the constitution of colonial education to the current republic - that was called here as Coloniality of education. In these paths there were and there are resistance moviments, such as the Countryside Education Moviment, characterized as an insurgent decolonial phenomenon starred by the people and social movements of the countryside, and that has enunciated alternative epistemologies in the confrontation and resistance to colonial violence. It is emergent the strengthening of practices, knowledge and experiences of this decolonial project of education, which has the potential to develop new epistemologies, ontologies and forms of institutional and non-institutional education

Keywords: coloniality; urbancentrismo; rural education; field education; decoloniality.

\section{EDUCACIÓN DE LOS PUEBLOS DEL CAMPO EM BRASIL: COLONIALIDAD / MODERNIDAD Y URBANOCENTRISMO}

RESÚMEN: Las fuerzas de la colonialidad y la modernidad se forman a partir de la colonización de América, sus bases son intrínsecas al urbancentrismo, que se basa en la égida de la civilidad, basada en las dicotomías entre el urbano-superior y el rural-inferior. En este proceso histórico, la gente del campo sufrió y sufre la herida colonial por la colonialidad del poder, del conocimiento, del ser y de la naturaleza. Las formas de subordinación de los sujetos campesinos están estructuradas, ellas deslegitimán sus expresiones epistémica, económica, cultural y social en la constitución de Brasil. Esto se refleja en la construcción de la educación escolar brasileña, que a lo largo de la historia ha estado bajo el criterio urbano / colonial / moderno, (re) produciendo relaciones de inferiorización de mujeres y hombres rurales, teniendo sus marcas desde la constitución de la educación colonial hasta la república - lo que aquí se llama la Colonialidad de la educación. En estos caminos hubo y hay movimientos de resistencia, como el Movimiento de Educación del Campo, caracterizado como un fenómeno decolonial insurgente llevado a cabo por los pueblos y los movimientos sociales campesinos, y que ha enunciado epistemologías alternativas en la confrontación y resistencia a la violencia colonial. Es emergente el fortalecimiento de las prácticas, los conocimientos y las experiencias de este proyecto de educación decolonial, que tiene el potencial de desarrollar nuevas epistemologías, ontologías y formas de educación institucional y no institucional

Palabras clave: colonialidad; urbancentrismo; educación rural; educación del campo; decolonialidad.

\section{INTRODUÇÃO}

Essa pesquisa debruça-se sobre a historicidade da educação escolar no Brasil, na busca de compreender como a colonialidade/modernidade e o urbanocentrismo a estruturou, e, especificamente, como tem atingido a educação dos povos do campo.

Primeiramente é essencial sinalizar sob qual paradigma se constrói esse estudo, principalmente seus aspectos geo-corpo-políticos ${ }^{1}$, tendo em vista que esses fatores são determinantes para se compreender o desenvolvimento das análises aqui colocadas. Desta maneira, esse trabalho tem por base os estudos decoloniais latino-americanos, que se constituem centralmente a partir da rede de estudos Modernidade/Colonialidade. Essa rede de estudos vem se construindo desde o final do século XX, a partir dos diálogos latino-americanos que se propõem a elaborar questionamentos sobre os processos de modernidade/colonialidade que envolveram os povos latinos-americanos a partir de relações eurocêntricas, de dominação, inferiorização e subordinação cultural, social, epistêmica e ontológica (BALLESTRIN, 2013).

Essa perspectiva busca discutir, afirmar e potencializar movimentos de resistências em uma perspectiva decolonial, ou seja, superar padrões de poder eurocêntricos que perpassam as relações sociais. Além disso, a perspectiva decolonial vem romper silenciamentos e ausências de grupos marginalizados, afirmando esses sujeitos enquanto agentes epistemológicos, políticos e sociais, para se pensar modos de 
conceber a existência de outros, que foram sufocados pela modernidade/colonialidade. Desta forma, esses estudos estão estreitamente ligados com os Movimentos Sociais (Camponês, Indígena, Negro, Feminista) na América Latina (SILVA et. al., 2014; CASTRO-GÓMEZ; GROSFOGUEL, 2007; BALLESTRIN, 2013).

A rede Modernidade/Colonialidades se caracteriza como um espaço recente, que se apoia em pensamentos sociais do século XX e XXI (teorias pós-coloniais, marxistas contemporâneos, análises do sistema-mundo, correntes dos movimentos sociais), e vem compartilhando "noções, raciocínios e conceitos que lhe conferem uma identidade e um vocabulário próprio, contribuindo para a renovação analítica e utópica das Ciências Sociais latino-americanas do século XXI" (BALLESTRIN, 2013, p. 99). Alguns textos, autoras e autores compõem essa rede e são utilizados ao longo desse trabalho: Quijano (2005, 2009, 2014), Bernardino-Costa e Grosfoguel (2016), Castro-Gómez e Grosfoguel (2007), CastroGómez (2005), Dussel (2005), Grosfoguel (2016; 2009), Lander (2005), Maldonado-Torres (2007; 2009), Mignolo (2005; 2007; 2011), Porto-Gonçalves (2005) e Walsh (2008).

Operando aqui um percurso pautado na reflexão crítica sobre a história da educação escolar brasileira, esse trabalho busca entender como a educação dos povos camponeses vem se consolidando a partir de um projeto histórico pautado na modernidade/colonialidade e urbanocentrismo, compreendendo os efeitos nocivos e expondo as práticas decolonias de resistência a essa "ordem geopolítica mundial que é conformada por uma clivagem estruturante moderno-colonial e que só pode ser compreendida a partir dessa tensão que a habita”. (PORTO-GONÇALVES, 2005, p.3-4).

Assim, o objetivo desse trabalho é analisar os processos de colonialidade/modernidade e urbanocentrismo como categorias que explicam a subaltenização dos povos do campo, destacando a constituição histórica da educação formal brasileira. E, por fim, propõe-se o debate da Educação do Campo enquanto movimento de resistência a essa colonialidade histórica, o compreendendo como fenômeno decolonial. A sustentação dessa tese se alicerçará a partir de alguns trabalhos de autoras e autores que defendem tal perspectiva, como Silva, Torres e Lemos (2012), Silva e Silva (2013), Silva et al. (2014) e Farias e Faleiro (2018).

\section{COLONIALIDADE/MODERNIDADE E URBANOCENTRISMO}

De acordo com Quijano (2005), através da noção de raça que se consolida os processos de subalternização dos povos marginalizados (negros, indígenas, entre outros). Para esse autor a ideia de raça constitui-se no contexto de colonização da América e operou (e segue operando) as divisões/classificações sociais, produzindo as dicotomias colonizador-superior/colonizado-inferior. "A ideia de raça, em seu sentido moderno, não tem história conhecida antes da América. Talvez se tenha originado como referência às diferenças fenotípicas entre conquistadores e conquistados, mas o que importa é que desde muito cedo foi construída como referência a supostas estruturas biológicas diferenciais entre esses grupos" (QUIJANO, 2005, p.117). Criou-se novas identidades sociais (indios, negros e mestiços) e redefiniu outras (europeus), junto a isso foram instituídas classificações com conotação racial, produzindo relações de dominação, associadas a hierarquias, lugares e papéis sociais. Logo, essas divisões sociais e raciais se configuraram para justificar as relações de dominação; tais identidades foram associadas a lugares de poder e saber, definindo quem subordina (europeu branco) e quem é subordinado (indígenas e africanos). "Em outras palavras, raça e identidade racial foram estabelecidas como instrumentos de classificação social básica da população". (QUIJANO, 2005, p.117).

Quijano (2005) pontua que historicamente as forças colonialistas e capitalistas europeias consolidaram um novo padrão de poder e dominação mundial, exercido pelos processos de inferiorização raciais, territoriais, controle das relações de produção, recursos e força de trabalho, com base no capital e no mercado mundial, afirmando a construção de uma supremacia branca europeia. O estabelecimento desse padrão de poder etnocêntrico (eurocêntrico) sobre o mundo, centralmente sobre a América e a África (a partir da exploração desses povos e da inferiorização de suas identidades), constrói um padrão cognitivo, ou seja, em que o conhecimento do não-europeu (o negro e o índio) se torna passado, primitivo, irracional e inferior.

A partir disso, sobretudo no século XVII a Europa consegue se consolidar enquanto centro da civilidade e do conhecimento do mundo, com base na exploração e inferiorização da América e na 
exploração de mão-de-obra escrava. O "processo de modernidade produziu uma perspectiva de conhecimento e um modo de produzir conhecimento que demonstram o caráter do padrão mundial de poder: colonial/moderno, capitalista e eurocentrado" (QUIJANO, 2005, p.126). Nesse sentido, a Europa e seu povo constroem o mito da modernidade eurocentrada, em que eles passam a ser os modernos da humanidade, colocando-se como os principais protagonistas da história do mundo. Esse território foi capaz "de difundir e de estabelecer essa perspectiva histórica como hegemônica dentro do novo universo intersubjetivo do padrão mundial do poder" (QUIJANO, 2005, p. 122).

Logo, o processo se consolidou pautado em dois movimentos: apropriação das populações colonizadas, na busca do desenvolvimento do capitalismo que beneficiasse o centro europeu; e na repressão de diferentes "formas de produção de conhecimento dos colonizados, seus padrões de produção de sentidos, seu universo simbólico, seus padrões de expressão e de objetivação da subjetividade" (QUIJANO, 2005, p. 121), na procura pelo despojamento das formas de existências, epistemologias e culturas dos povos colonizados, desqualificando as experiências vividas não europeias.

Desse modo, o colonialismo se qualifica como uma das mais estruturadas armas do eurocentrismo econômico, sociocultural, epistêmico e político, e mesmo com o fim do colonialismo político (dominação que nega a independência política de povos subjugados), não se colocou fim nas desigualdades e hegemonias por ele geradas, o que permaneceu na forma de colonialidade. "La colonialidad, en consecuencia, es aún el modo más general de dominación en el mundo actual, una vez que el colonialismo como orden político explícito fue destruido" (QUIJANO, 2014, p. 63). Essa colonialidade é exercida nos dias atuais, ou seja, se estrutura em um padrão de poder, saber e ser centrado em uma ciência eurocêntrica, resultado do colonialismo, que ainda invisibiliza e deslegitima outras formas de conhecimento a partir de outras experiências sociais. O colonialismo/colonialidade leva à produção de uma cegueira aos modos de existir, pensar e conceber a realidade não-europeia, levando à reprodução das relações coloniais/imperiais pautadas em uma modernidade etnocêntrica, é uma perspectiva que impede observar que não há somente a Europa como espaço de ativo de enunciação de modos de organizar a realidade social (MALDONADO-TORRES, 2009; PORTO-GONÇALVES, 2005).

Um exemplo das questões que envolvem a colonialidade/modernidade, que se evidencia a partir do capitalismo atualmente, é o neoliberalismo e sua capacidade de se colocar como concepção hegemônica, se torna o "conhecimento objetivo, científico e universal e sua visão da sociedade moderna como a forma mais avançada, e, no entanto, a mais normal da experiência humana, está apoiada em condições histórico-culturais específicas" (LANDER, 2005, p.08). Não se torna apenas hegemonicamente na economia, mas na difusão de modos de vida pautados nessa lógica, desclassificando ações alternativas a essa concepção capitalista/colonial/moderna.

Nesse percurso, entende-se que a modernidade está intrínseca à colonialidade, bem como o capitalismo (MALDONADO-TORRES, 2009). Mignolo (2005, p. 36) afirma que "não pode haver modernidade sem colonialidade; que a colonialidade é constitutiva da modernidade, e não derivativa". Assim se sustenta o eurocentrismo, partindo da criação da modernidade europeia e as relações de colonialidade com o resto do mundo, dominando os processos e o desenvolvimento desses países e criando para subalternidades os sujeitos não-eurocêntricos.

Desse ponto de vista, as relações intersubjetivas e culturais entre a Europa, ou, melhor dizendo, a Europa Ocidental, e o restante do mundo, foram codificadas num jogo inteiro de novas categorias: Oriente-Ocidente, primitivo-civilizado, mágico/mítico-científico, irracional-racional, tradicional-moderno. Em suma, Europa e não-Europa. (QUIJANO, 2005, p.122).

Nota-se que a colonialidade/modernidade/capitalista se sustentam a partir dessas dicotomias que afirmam o lugar de dominação da Europa contra a não-Europa; nessa tônica há a constituição de classificações sociais - sujeitos inferiores (dominados - índios, negros, camponeses) e superiores (dominadores - supremacia branca, masculina, urbana) (DUSSEL, 2005). Pautados nas questões raciais, geopolíticas e no fortalecimento da Europa enquanto centro da modernidade, que justifica a invasão cultural, econômica e política de outros continentes.

A partir das transformações sociais, como a superação do colonialismo, há a consolidação dos Estados-nações periféricos, em um sentido eurocêntrico (QUIJANO, 2005), em que ainda perpassa e finda as relações de colonialidade global. Essa colonialidade global se configura, não saindo da sua 
característica eurocêntrica, mas se potencializando a partir de outras perspectivas, como o próprio imperialismo norte-americano e europeu, que tem articulado formas de dominação socioeconômica e cultural com a América Latina. O reflexo disso são as perspectivas neoliberais, já citadas anteriormente, que vêm se colocando a partir das novas instituições do capital, como a Fundo Monetário Internacional - FMI, Banco Mundial, bem como instituições de inteligência que se consolidaram pós-Segunda Guerra e vem mantendo as relações de subordinação com a América Latina, a partir da ideia de globalização².

Cabe sinalizar que o eurocentrismo não beneficia apenas populações europeias, mas as populações de origem ou que assimilam as concepções europeias que estão em "todas partes del mundo que gozan de los privilegios de la supremacía blanca en relación a poblaciones de origen no-europeo" (GROSFOGUEL, 2016, p.04). Assim, a crítica a esse movimento se dá a todos os sujeitos que fazem manutenção desses sistemas de dominação para se colocarem em lugares de poder.

Por esse ângulo, entende-se que o Urbanocentrismo também está intrínseco à construção da colonialidade/modernidade, tendo em vista que o ideal moderno e civilizatório para se constituir o homem moderno, estavam vinculados com os modos de vida (cultura, comportamentos) e produção (capitalista industrial) urbanos. As inserções dos espaços rurais no processo de civilização se dão apenas por vias que deslegitimam e desqualificam os modos de existência e expressão cultural desses, ou na exploração da natureza - como o agronegócio. Essa concepção "privilegia o pólo urbano do continuum como a fonte do progresso e dos valores dominantes que se impõem ao conjunto da sociedade. $O$ extremo rural do continuum, visto como o pólo atrasado tenderia a reduzir-se sob a influência avassaladora do pólo urbano" (WANDERLEY, 2001, p.32). Assim, o espaço não-urbano é deslegitimado enquanto território de enunciação epistêmica, ontológica, econômica e cultural.

Os vestígios dessa concepção podem ser vistos a partir das análises realizadas por González Stephan (1995) ao estudar os manuais de urbanidade impostos a América Latina no século XIX, que tinham como objetivo direcionar a formação de sujeitos civilizados para atingir o ideal de modernização eurocêntrica, a partir de um padrão de cidadania normatizado e que exclui qualquer existência que fuja do padrão normativo-moderno-eurocêntrico. "A aquisição da cidadania é, então, um funil pelo qual só passarão aquelas pessoas cujo perfil se ajuste ao tipo de sujeito requerido pelo projeto da modernidade: homem, branco, pai de família, católico, proprietário, letrado e heterossexual" (CASTRO-GÓMEZ, 2005), e, obviamente, urbana. Não existiam manuais para que direcionassem a constituição de um perfil ideal de camponês, de negro ou de índio, pois esses já eram considerados no âmbito da barbárie, da irracionalidade, da impossibilidade de vivenciar e enunciar modos de vida legítimos. Os manuais eram para sujeitos que estava sob um território (urbano) legítimo de enunciação epistêmica, moral, racional e estética. Assim, pensa-se centralmente na constituição a partir da colonialidade, de bons cidadãos, constróise o ideal de cidadania ${ }^{3}$.

La cuestión, era ser um hombre o mujer de apariencia $<<$ civilizada $>>$; que sus modales no dejaran translucir ningún rasco o gesto que recordara viejos usos rurales, probablemente tildados de $<<$ inciviles $>>$ o $<<$ bárbaros $>>$ por esta nueva sociedad cada vez más estirada como moderna. (GONZÁLEZ STEPHAN, 1995, p.434).

Há assim a construção de um abismo dual, em que 'a 'entrada' no banquete da modernidade demandava o cumprimento de um receituário normativo que servia para distinguir os membros da nova classe urbana que começava a emergir em toda a América Latina durante a segunda metade do século XIX” (CASTRO-GÓMEZ, 2005, p.82). Onde os territórios rurais e seus sujeitos não possuem espaço, criando o abismo - a inexistência destes. Enraíza-se o abismo entre um "nós" modernos-urbanoseurocêntrico-normativos, e os "outros" que estão no âmbito da barbárie, irracionalidade, atraso, antigo. Pois, esse processo de diferenciação exigia ampliar os mecanismos e as ideias de distinção, para legitimar a norma enquanto o ideal e o correto, assim, a urbanidade se torna o critério de distinção fundamental para a consolidação do padrão de poder urbano/eurocêntrico/moderno. (GONZÁLEZ STEPHAN, 1995).

Criar a identidade do cidadão moderno na América Latina implicava gerar uma contraluz a partir da qual essa identidade pudesse ser medida e afirmada como tal. A construção do imaginário da civilização exigia necessariamente a produção de sua contraparte: o imaginário da barbárie. (CASTRO-GÓMEZ, 2005, p. 82, grifos do autor). 
Cabe destacar que a criação dessa estrutura abissal, e assim, a ideia de modernidade eurocêntrica, se dá desde o descobrimento das Américas e o processo de colonização, para assim, justificar o padrão de dominação aos outros povos, caracterizando também as relações pré-capitalistas ${ }^{4}$ (QUIJANO, 2005). Essas normas difundidas e legitimadas na América Latina excluem, então, a existência, enquanto sujeitos, agentes de direitos, de legitimidade cultural e social, os povos que vivem no campo. Não podendo esquecer que esse padrão de ser, posto arbitrariamente, está baseado na constituição do homo economicus, em que o capitalismo vai tomando a centralidade como modelo socioeconômico ideal moderno. (CASTRO-GÓMEZ, 2005).

Desta maneira, entende-se que esses padrões de poder pautados no eurocentrismo/colonialidade/modernidade e urbanocentrismo, que se constroem desde a invasão das Américas (e a invenção do outro, a partir de dicotomias) e vão se fortalecendo no decorrer dos séculos, perpassam a existência, e, sobretudo, configuram-se sob a dominação e subordinação da população do campo. Mediante isto, no próximo tópico busca-se compreender como esses processos se dão olhando especificamente para as colonialidades que atingem esses sujeitos.

\section{COLONIALIDADES E OS SUJEITOS DO CAMPO}

Pode-se identificar que essa colonialidade perpassa a existência e as relações sociais nos seguintes eixos: colonialidade do poder, do saber, do ser e da natureza. Sob o viés freireano, essas colonialidades se dão pela invasão cultural, ou seja, na "penetração que fazem os invasores no contexto cultural dos invadidos, impondo a estes a sua visão do mundo, enquanto lhes freiam a criatividade, ao inibirem sua expansão" (FREIRE, 1987, p. 86). Desta forma, as colonialidades que se discorre aqui, se dão a partir desse movimento, focando, especialmente, nos povos do campo brasileiro. Assim, pretende-se refletir sobre os impactos dessas colonialidades, que são intrínsecas a modernidade, urbanocentrismo e ao capitalismo, nos sujeitos do campo que sofreram e sofrem a ferida colonial.

A Colonialidade do Poder se refere à construção do padrão de poder historicamente constituído sob as bases da modernidade/eurocentrismo, que se apoiam a partir dos critérios raciais/étnicos, gênero, território, trabalho e sobre a ideia de racionalização, padrão de pensar e de se viver. Assim, tudo que foge aos padrões impostos pela colonialidade do poder (que confere poder de dominação) não possui legitimidade para o exercício de poderes, pois não segue os critérios coloniais/modernos/europeus, pelo contrário, servem para legitimar a superioridade eurocêntrica e seu poder de dominação. Edificou-se, então, classificações sociais, que legitimam lugares do dominador e dominado - opressor e oprimido patrão e empregado - superioridade racial/étnica/geográfica e inferioridade racial/étnica/geográfica (QUIJANO, 2005).

Silva et al. (2014) sinalizam que a colonialidade do poder subsidia a construção da dicotomia cidade-campo; a partir do urbanocentrismo a cidade é tomada como lócus de enunciação legítimo e o campo é subalternizado à vida citadina, por meio da inferiorização cultural, social, epistemológica, racial/étnica e econômica (SILVA, TORRES; LEMOS, 2012). Ou seja, a identidade camponesa é marginalizada para potencializar o padrão eurocêntrico, moderno, colonial e capitalista da identidade urbana, que vira a referência de bom cidadão (SILVA; SILVA, 2014). Existe, assim, a estruturação de um padrão de poder urbano, que busca criar representações sociais de um campo bárbaro, atrasado, inferior, onde as existências dos sujeitos que ali se constroem são desumanizadas. Procura-se criar complexos de inferioridade, na busca de silenciamento, para que assim o padrão urbano não tenha qualquer ameaça de imperar enquanto verdade natural. Essa colonialidade se reafirma a partir da epistemologia eurocêntrica, e assim, transforma-se também um uma Colonialidade do Saber.

A Colonialidade do Saber aponta para a ferida em uma perspectiva epistemológica eurocêntrica, que deslegitima e inviabiliza olhar para outros sujeitos epistemológicos, minando a consolidação de processos que considerem a diversidade de pensamento que as múltiplas experiências no mundo desenvolvem (PORTO-GONÇALVES, 2005). Isso leva a um apagamento de epistemologias, através do silenciamento e dos próprios genocídios que ocorreram nas resistências coloniais. O padrão de saber eurocentrado realiza ações para reprimir "as formas de produção de conhecimento dos colonizados". (QUIJANO, 2005, p.121). 
Esse processo impacta nos sujeitos do campo "impondo a validade epistêmica ao lócus urbano e descredibilizando as epistemologias campesinas, originadas das matrizes culturais desses povos considerados inferiores e, portanto, não validados a produzir conhecimento" (SILVA et al., 2014, p.15). Assim, esse lugar que não atende a norma arbitrariamente imposta enquanto natural, é descartado enquanto lugar de enunciação de conhecimento, de saberes válidos, impossibilitando a inserção de suas perspectivas de mundo nos processos de constituição social (SILVA; TORRES; LEMOS, 2012). Esses eixos da colonialidade acabam desenvolvendo a colonialidade da própria existência do ser, o que não pode e o que não sabe acaba não sendo - Colonialidade do Ser.

A Colonialidade do Ser resulta da dinâmica da colonialidade do poder e do saber, se dá nos processos de dominação que foram vivenciados historicamente e culturalmente. Há a produção de representações sociais a partir da colonialidade do ser, e esta é base para constituição do ser negro, ser camponês, ser mulher, ser latino-americano, ser superior, ser inferior. Maldonado-Torres (2007) aponta essa construção a partir da ideia cartesiana "penso, logo existo", dinâmica difundida a partir do eurocentrismo, modernidade e urbancentrismo. Assim, quem pensa é o sujeito moderno/europeu, logo ele existe, ele é (ser). Porém, a partir da colonialidade do saber, os sujeitos colonizados/latinos-americanos, não pensam (pois possuem suas epistemológicas deslegitimadas - aponta como irracional - representadas socialmente nesse sentido), sendo assim, eles não existem, não são (ser).

Essa ideia tem suas raízes nos processos de colonização, e se potencializa com a ideia cartesiana, através agora não mais da teologia (seu papel se torna secundário), mas da construção da ciência moderna/ocidental. " La ausencia de la racionalidad está vinculada en la modernidad con la idea de la ausencia de 'ser' en sujetos racializados" (MALDONADO-TORRES, 2007, p. 145). Ademais, a partir da colonialidade há o aniquilamento das possibilidades de ser, de se construir identidades e ontologias a partir da sua existência negra, indígena, camponês, feminina, entre outras, é a negação da humanidade. (QUIJANO, 2005).

Esses aspectos atingem os sujeitos do campo na medida em que agenciam processos de incorporação banalizados por concepções estereotipadas, inferiorizadas, de atraso e ignorância do ser do campo. Justificando ordens de desumanização, ou seja, retirando suas potências enquanto sujeitos políticos, sociais, epistêmicos e culturais e de direitos, silenciamento do ser (SILVA et al., 2014; SILVA; TORRES; LEMOS, 2012). "A Colonialidade do Ser refere-se ao processo pelo qual o senso comum e a tradição são marcados por dinâmicas de poder de caráter preferencial: discriminam pessoas e tomam por alvo determinadas comunidades" (MALDONADO-TORRES, 2009, p.363). Fortalecendo as dicotomias entre cidade-campo, reforça-se a discriminação do campo, para que assim, não haja qualquer possibilidade de considerá-los enquanto sujeitos que são (SILVA; SILVA, 2014).

A Colonialidade da Naturęa, esse eixo se consolida segundo a construção de um binarismo entre natureza e sociedade, que se dá pela própria ideia de colonialidade do poder e saber, fundada na concepção eurocêntrica/moderna/civilizatória/urbana, em que a relação do homem colonizador com a natureza acontece alicerçada na dominação, exploração e expropriação. De acordo com Walsh (2008), isso se constrói no momento que há a deslegitimação das relações entre o mágico-espiritual-socialancestral e a natureza, enquanto sistemas integrados de muitos povos subalternizados da América Latina (índios, negros, camponeses).

Al negar esta relación milenaria, espiritual e integral, explotar y controlar la naturaleza y resaltar el poder del individuo moderno civilizado (que aún se piensa con relación al blanco europeo o norteamericano) sobre el resto, como también los modelos de sociedad «moderna» $\mathrm{y}$ «racional» con sus raíces europeo-americanas y cristianas, este eje de la colonialidad ha pretendido acabar con todo la base de vida de los pueblos ancestrales, tanto indígenas como afrodescendentes. (WALSH, 2008, p.139).

As relações com a natureza, que demarcam outras experiências sociais, voltadas para conservação, ancestralidade e integração, vão ao desencontro com a dominação colonial, e fundamentalmente com as lógicas socioeconômicas capitalistas. Assis (2014) coloca a Colonialidade da Natureza como uma estratégia de acumulação de capital fundada na exploração dos territórios e recursos naturais da América Latina. Assim, ocorre uma construção a partir da égide modernidade/colonialidade/eurocentrismo/urbanidade de formas de exploração econômica- 
instrumentais de expropriação da natureza para a acumulação de capital e a conservação do poder socioeconômico eurocêntrico, ou seja, conservação do padrão de poder moderno/colonial. Essa colonialidade toma a existência de hegemonias de extração e compreensão da natureza, considerando-a como recursos mercadológicos, e nesse sentido, deslegitima as relações de respeito dos negros, indígenas e camponeses com a natureza para justificar as relações de poder e dominação com a terra e com os sujeitos que vivem nela.

Essa colonialidade atinge os sujeitos do campo, pois seus territórios passam a ser considerados como espaços a serem explorados pelo capital - agronegócio. Há a coisificação do território dos sujeitos do campo, onde o homem moderno - que preza o progresso econômico - tem o poder e o direito de explorar esse território (SILVA; TORRES; LEMOS, 2012). Para o camponês é um território de vida, de produção de subjetividade, de sentidos, ancestralidade e cultura, assim, já para a ordem da colonialidade é um espaço a ser explorado e seus habitantes silenciados.

"De acordo com os eixos da Colonialidade os sujeitos não podem, não sabem e não são, portanto, seus territórios de origem são insignificantes" (SILVA et al., 2014, p.16). Nota-se então a construção de um movimento complexo de colonialidade, que se estabelece pelo silenciamento, abafamento e extermínio dos modos de existência dos povos do campo, a partir de múltiplos processos urbanocentrados/eurocentrados/civilizatórios/modernos, que se consolidam historicamente e atualmente a partir de diversas estratégias de dominação socioeconômica, cultural e educacional. Desta maneira, a partir desse entendimento, que dá luz à reflexão que o trabalho se propõe, tenta-se aqui olhar como se consolida a Educação nos territórios do campo, tendo em vista a Colonialidade do poder, saber, ser $e$ da natureza, que subalternizam os sujeitos do campo.

\section{EDUCAÇÃO E CAMPO - Colonialidade da Educação}

A educação é compreendida como prática social, cultural e histórica, que se caracteriza a partir de movimentos de formação de sujeitos, ocorrendo em espaços institucionais e não-institucionais (GONDRA; SCHUELER, 2008). Aqui as reflexões serão realizadas apoiadas nesses dois contextos, porém, centralizaremos em aspectos que envolvem a construção da educação institucional no Brasil - a educação escolar.

Compreende-se a educação escolar enquanto espaço de reprodução e produção, que perpassa a existência de variadas finalidades de acordo com as conjunturas e as historicidades. Destarte, a sociedade, a família, a religião, a estrutura sociopolítica e cultural em determinados contextos históricos delegaram à educação escolar finalidades, que dentro das estruturas de poder se colocam em certa medida submetidas a essas demandas no processo de transmissão de conhecimento e difusão de certos comportamentos. Porém, entende-se que esse lugar não seja apenas reprodução dessas demandas, mas também se estabelece e se produz processos e estratégias próprias de educação de sujeitos, marcados pelas demandas externas, mas que produzem funcionamentos internos, que acaba caracterizando a cultura escolar ${ }^{5}$ (JULIA, 2001).

Deste modo, entende-se que as colonialidades perpassam a existência, consolidação, reformas, dinâmicas e finalidades da educação escolar, na consolidação das suas finalidades, e por consequência na produção da cultura escolar. Mediante isso, aqui se busca constatar que no Brasil perpassa um processo que se denomina como a Colonialidade da Educação, ou seja, há a consolidação de uma estrutura de educação institucional que é cortada pelo colonialismo e pela colonialidade, e todos os movimentos de modernidade/ urbanocentrismo/ civilidade/ eurocentrismo/ capitalismo que estão intrínsecas a essas perspectivas. Tendo como finalidade compreender, especificamente, como a educação nos territórios do campo foram se constituindo dentro deste processo.

A escola historicamente se constrói enquanto lugar de incorporação das ideias da modernidade, e assim, enquanto espaço urbanocentrado, tendo suas demandas direcionadas para os aspectos que marcam a cidade. $\mathrm{Na}$ realidade nacional essas perspectivas se consolidam fundadas no colonialismo e logo em seguida na colonialidade. Dentro dessas questões a escola tem sua forma articulada com as finalidades da modernidade/urbanocentrismo, porém, a escola não se coloca na reprodução dessa nova ordem, mas também acaba participante das produções de modos de existência que as legitime, em busca da ordem - normatização de corpos a partir da civilidade. Assim, a normas 
eurocêntricas desencadeiam historicamente no Brasil, onde as ideias de modernidade urbanocêntrica e civilidade tomam a escola como lócus privilegiado das ações para disseminação das ordens, onde é espaço de desenvolvimento social e cultural em prol do progresso moderno. (GONZÁLEZ STEPHAN, 1995). Pode-se dizer "[...] que existem temas e momentos do fazer histórico em que é possível visualizar com muita nitidez este cruzamento entre o escolar e o urbano". (FARIA FILHO, 2005, p.31).

Dentro da égide da modernidade eurocêntrica e colonial, a escola se constrói enquanto espaço onde os processos pedagógicos institucionais se articulam para a materialização de um país com base na modernidade. "A escola transforma-se num espaço de internamento onde se forma esse tipo de sujeito que os ideais reguladores [...]. O que se busca é introjetar uma disciplina na mente e no corpo [...]" (CASTRO-GÓMEZ, 2005, p.82) que legitime as ideias das colonialidades, e a partir da epistemicídio de outras maneiras de se conceber a realidade. Há uma busca pela homogeneização dos sujeitos, em que o comportamento "deverá ser regulamentado e vigiado, submetido à aquisição de conhecimentos, capacidades, hábitos, valores, modelos culturais e estilos de vida" (CASTRO-GÓMEZ, 2005, p. 82) eurocentrados, e que são dispostos para uma parcela privilegiada da população, historicamente o acesso se restringe aos sujeitos que possuem uniformidade a partir dos critérios de raça, gênero, comportamento e epistemologia.

A escola se coloca como o lugar de difusão e homogeneização de sujeitos predispostos (brancos, elites, urbanos) a se encaixarem dentro dos critérios da modernidade. Historicamente há inserções, as mulheres, negros, camponeses e índios são introduzidos dentro desses espaços escolares, mas há uma infinidade de critérios que permanecem inferiorizando e (re) produzindo modelos de dominação. Como o processo de introdução da Educação nos territórios rurais, que aconteceu depois de séculos de invisibilidade, e que ocorreu (re) produzindo ideias de marginalização e inferiorização cultural, de forma precarizada, conservando estruturas de poder (LEITE, 1999). Leite (1999, p.14) afirma que

A educação rural no Brasil, por motivos sócio-culturais, sempre foi relegada a planos inferiores, e teve por retaguarda ideológica o elitismo acentuado do processo educacional aqui instalado pelos jesuítas e a intepretação política-ideológica da oligarquia agrária conhecida popularmente na expressão: "gente da roça não carece de estudos. Isso é coisa de gente da cidade ". (anônimo).

A trama que envolve a educação nesses territórios geograficamente demarcados, mas que, sobretudo, comportam modos de vida diversos, é desenvolvida historicamente a partir de diversas ideologias, demarcada pela dicotomia rural-inferior e urbano-superior. Silva, Torres e Lemos (2012) pontuam essas trajetórias de marginalização dos povos do campo, que marcam desde as capitanias hereditárias até o processo do agronegócio, enquanto espaço sempre de expropriação dos sujeitos e dos objetos, onde a educação escolar se articulou enquanto possibilidade para inculcar ideias de inferiorização, urbanocêntricas e desumanizadoras.

Esses movimentos na educação brasileira são nítidos em cada período, seja em uma perspectiva teológica (renascentista, cristã) ou egológica (moderna, cartesiana), sendo a ideia de modernidade eurocêntrica universalizada, e assim, intrínseca dentro de todo esse processo, bem como o urbanocêntrico e o capitalismo enquanto sistema universal. É importante reafirmar que quando se refere a grupos que legitimam e (re) produzem a colonialidade, não se refere somente aos sujeitos de origem europeia, mas também aos próprios grupos (elites locais) brasileiros que se beneficiaram e exerceram o processo de dominação eurocêntrica, com base na modernidade, branca e no urbanocentrismo - as elites intelectuais, religiosas, políticas, latifundiárias. Assim, a crítica se dá a todos esses sujeitos, que subordinaram e subordinam através do eixo da modernidade/colonialidade, os povos negros, indígenas, as mulheres e os povos do campo.

O marco da Colonialidade da Educação é na própria colonização do Brasil, constrói-se as identidades sociais (europeu, negro, índio) a partir das relações de poder e hierarquia racial, em que há a inferiorização do povo que já habitava esse território, e do povo negro escravizado, fundando a ideia da superioridade europeia enquanto a identidade superior nas relações coloniais (QUIJANO, 2005).

Nesse percurso da colonização - Brasil Colônia $(1500$ - 1822) , a escola se torna espaço de articulação e difusão cultural, na formação da elite que comandaria essas novas terras, que em determinados momentos quis aculturar os índios via escolarização, buscado a domesticação dos mesmos. E o negro, objetificado e animalizado, não entrava, sequer, como possibilidade de ser pensado no 
processo de escolarização. Paiva (2003, p.44) aponta que "os portugueses colonizadores só tinham uma visão de sociedade, visão esta que se realizava na sua sociedade e, portanto, tendo-a como modelo, agiam segundo em seu relacionamento com as demais culturas". Desta forma, a escola se consolida a partir de apenas uma epistemologia, colonizadora, onde se inicia o processo em que a Europa se coloca como centro do mundo a partir das relações de poder fundadas com a América, e que se fundamentavam sobre a busca obsessiva pelo novo. (PORTO-GONÇALVES, 2005).

Há um epistemicído de outras visões de sociedade e de organizações de vida. As formas de vida indígenas e negras são exterminadas, que se aproximam do que veio a se consolidar enquanto a população rural, com suas relações ancestrais, históricas e culturais com o meio ambiente, as relações comunitárias, as alternativas agrícolas. Pode-se dizer que essas estruturas já ditam o urbanocentrismo, e já estereotipam os sujeitos que vivem em proximidade com a natureza, como animais, bárbaros, sem alma e sem cultura. Ocorre a colonialidade do ser, a partir do padrão de poder, saber e dominação territorial, os "padrões de produção de sentidos, seu universo simbólico, seus padrões de expressão e de objetivação da subjetividade" (QUIJANO, 2005, p. 121) não-europeus são reprimidos e exterminados, onde na escola apenas a cultura eurocêntrica é passível de enunciação, com base fundamental na religião, para formar vigilantes culturais para não permitir outras formas de expressões na sociedade brasileira.

Essas marcas permanecem com as transformações das Reformas Pombalinas (com a expulsão dos Jesuítas da estrutura escolar), que agora se assentam sob uma nova perspectiva de modernidade, centrada principalmente na construção da ciência moderna (BOTO, 2011). Então, ainda sob a construção eurocêntrica, na tentativa de superar as perspectivas teológicas (na verdade ela é secundarizada), os pensamentos ilustrados e cartesianos impõem um novo sentido na modernidade que vem se construído desde a colonização. Compreendendo que "[...] las políticas teo- y ego-lógicas del conocimiento se basaron en la supresión tanto de la sensibilidad como de la localización geo-histórica del cuerpo “ (MIGNOLO, 2011, s/p), que se colocaram enquanto universais em uma só perspectiva (eurocêntrica). Desta maneira, ambas percepções articulam epistemicídios, porém, agora, a perspectiva egológica dos atributos vinculados a Deus se direcionam para o homem branco-ocidental-urbanomoderno, e seu poder de enunciar perspectivas universais de conhecimento, comportamento, existência se potencializa com base na ciência moderna. (GROSFOGUEL, 2009).

A construção dessas dicotomias, afirmam e direcionam para a própria dicotomia campocidade, afirmando a cidade enquanto sinônimo do progresso e do moderno. A educação se mantém dentro desses vieses, porém, agora se inicia a construção da educação gratuita à população da colônia, mas ainda não de forma igualitária em todo território, e fortemente voltada para políticas educacionais banalizadas no ideário ilustrado de enaltecer o Império Português. Com o processo que transformou o Rio de Janeiro em sede do Império Português, a política Joanina articula a criação da cidade "em símbolo da civilização" (GONDRA; SCHUELER, 2008, p. 25). Essa ideia segue na consolidação de uma educação para afirmação da elite ilustrada. Ocorrem ações precárias de educação nas áreas rurais, porém, a centralidade é no espaço urbano focando na assimilação de um ideal eurocêntrico para a formação dos vigilantes da cultura e para o próprio crescimento econômico e consolidação da ciência moderna (BOTO, 2011). Consequentemente, a difusão de qualquer espaço para a enunciação de povos subalternos na consolidação política, econômica e cultural no sistema educacional é inviabilizada, o Brasil ainda é um apêndice de Portugal, marcado pela dominação do saber, do ser e saber propriamente colonial.

Fonseca (2009, p. 323) reitera que "A urbanidade e a civilidade, pilares importantes para a educação das elites, teriam, assim, na figura do mestre o centro irradiador do exemplo", nesse contexto a educação toma como prioridade a inculcação desses comportamentos civilizatórios - urbanos, onde o próprio docente se torna exemplo desses aspectos do iluminismo, marcados pela moralidade cristã e a ciência moderna. Essa ideia se internaliza por toda a história da educação brasileira, baseada na negação e marginalização do campo enquanto espaço de produção epistêmica e cultural para compor o projeto societário. Tem a escola como papel fundamental, para disciplinar corpos e mentes, inculcar comportamento, distinções, classificações sociais vinculadas com a ideia eurocêntrica de superioridade, que se reiteram ao longo das conjunturas. (BOTO, 2014).

Mesmo direcionados por esse processo de modernização eurocêntrica, o Brasil se torna um Estado independente, Império do Brasil (1822 - 1889) (GONDRA; SCHUELER, 2008). Esse processo é essencial para compreensão da colonialidade no Brasil, pois aqui, a dominação europeia-moderna- 
colonial deixa de ser marcada pelo colonialismo formal, pois há uma emancipação política, e se torna uma dominação baseada na Colonialidade na essência do conceito.

A ideia de modernização e civilidade se potencializa, difundindo de maneira contundente as dicotomias entre cidade - rural, pois, além dos povos do campo não estarem nos espaços de difusão da cultura arbitrária (urbana e eurocêntrica), esses apresentavam forma de vida desarmônica com a nova lei da modernidade/capitalista/branca/letrada, tendo seu papel subalternizado no desenvolvimento dessa nação, pois não passavam pelo funil que determinava a civilidade (CASTRO-GÓMEZ, 2005), para a consolidação de um projeto nacional (invenção do Brasil), a partir de novas marcas culturais e urbanas, ainda de base eurocêntrica, para a constituição da comunidade nacional.

O Império se constrói no desejo por esse projeto político calcado na ideia de nação, com base no colonialismo/colonialidade e na modernidade, se manifesta "no incentivo às instituições educacionais, culturais e científicas e no mecenato às artes e à produção cultural" (GONDRA; SCHUELER, 2008, p. 28). Objetivando a formação escolar de elites especialistas que iriam difundir e produzir a ciência moderna, a literatura, língua pátria, conhecer o território do novo império, que (re) produziu as bases do colonialismo/colonialidade para se beneficiarem e legitimarem sua supremacia branca, burguesa e urbana em território nacional.

A educação imperial, de forma geral, dentre os diversos avanços, que almejavam uma educação pública nas províncias e o surgimento de leis educacionais, ainda tinha o acesso à escola pautado nas relações de distinção sob o crivo da superioridade e inferioridade. Assim, os negros, índios e camponeses ainda estavam à margem, considerados não-cidadãos, marcando principalmente os negros escravizados. Porém, ainda há a inserção e discussão de uma educação voltada para os índios, negros libertos, mulheres, que se deu a partir da domesticação desses corpos, civilização, sob critérios de civilidade branca/europeia/burguesa, com bases racistas, elitistas e moralistas, tendo em vista, que o próprio modelo de monarquia constitucional acautelado pelos defensores da liberdade da colônia que eram brancos e proprietários de escravos com o desejo de um Império que preservasse os seus privilégios (GONDRA; SCHUELER, 2008).

Assim, na constituição do Estado-nação, há a negação da participação dos povos subalternizados nas tomadas de decisões na organização social, política e educacional, a minoria branca se coloca no poder em agir e afirmar sua supremacia, mantendo sua expansão territorial (latifundiária) econômica, religiosa e cultural, com fonte no trabalho escravo. E, sobretudo, articulando políticas educacionais que tinha como foco a afirmação dessa supremacia e seus signos urbanos, tendo o campo como fonte de exploração. Quijano (2005, p. 134) afirma "os negros não eram nada além de escravos e a maioria dos índios constituía-se de povos da Amazônia, sendo desta maneira estrangeiros para o novo Estado. [...] [A configuração é a seguinte:] Estados independentes e sociedades coloniais", marcando a colonialidade arraigada nesses movimentos, em que a classe dominante eurocêntrica realizavam ações de manutenção do colonialismo sob a tônica da civilização de um país e formação de um povo. Cabe salientar que apesar de Quijano (2005) destacar os povos indígenas da Amazônia, estes estavam em todo território brasileiro, "da Amazônia ao litoral, a diversidade de povos, de línguas, de formas de organização social e política e como os índios, desde o início foram classificados pelos teóricos europeus de forma colonialista, evolutiva e preconceituosa sem considerar as especificidades locais e regionais". (CRUZ, 2017, p. 147).

Até aqui, nota-se processos que estabelecem um status quo, pois há estratégias de receitas transplantadas (coloniais/eurocêntricas/modernas) para as questões brasileiras. Essas ações não surgem de análises críticas da realidade nacional, mas que se consolidam na conservação de padrões de dominação que conservam a elite dominadora, que se beneficiam das colonialidades e as (re) produzem (FREIRE, 2016). A partir da República, essas estruturas colonialistas se conservam, mas, mais uma vez tomam formas diferentes, e é onde a pauta da Educação escolar dos povos do campo toma, em alguma medida, visibilidade, porém com variadas contradições para se manter o status quo da colonialidade.

Com a iniciação da República (1889 - atualmente) o ideal urbanocêntrico se centraliza mais do que nunca, a modernização e a colonialidade busca prescrever dinâmicas "con el nuevo estilo urbano de vida que se estaba deseando como emblema de la soñada $<<$ civilización $>>$ " (GONZÁLEZ STEPHAN, 1995, p. 432). Desta maneira, há a criação do urbano como espaço unicamente passível de progressos 
nacionais - os signos rurais colocados são colocados como incivilizados, abafando qualquer produção advinda desse território.

A escola permanece articulada com a agenda política-cultural para a civilização/modernidade/urbanização, onde se estabelece como o lugar onde se aprende comportamentos, gestos, formas e modos de existir elaborados a partir desses critérios arbitrários (BOTO, 2014). Criam-se liturgias nesse espaço que legitima a superioridade da vida civilizada/urbana, que, logicamente, baseia-se na construção do rural enquanto sinônimo do atraso. Cabe reafirmar que esse processo se potencializa na República, porém, suas raízes são históricas, a base desse processo pode ser vista a partir da análise da definição de ensino no Dicionário de lingual português de 1813: ensino “instrução, educação, urbanidade, direções, preceitos, máximas prudenciais e morais" (DICIONÁRIO, 1813, p. 707 apud BOTO, 2014). Assim, as concepções que coloca o ensinar no ambiente escolar como a busca e a imposição de estratégias de aculturação fundamentadas na cultura arbitrária urbana, moral, religiosa, eurocêntrica, branca, se reitera e se afirma na República, ganhando grande força com a expansão do sistema capitalista, que coloca a cidade como o centro da industrialização. Ademais, as liturgias da aprendizagem e do ensino estão estreitamente relacionadas com as normas do comportamento civilurbano e a negação e inferiorização de signos que constituem a vida rural.

Boto (2014, p. 112) sinaliza que "a civilidade é um dos princípios estruturais do processo de socialização escolar", sendo uma civilização conservadora, pois essa se tange sob os discursos de hierarquia e classificação sociais, de superioridade e inferioridade, subordinação entre pessoas. Assim, com a ideia de urbanidade, a subordinação do campo pela cidade ocorre nesse processo de socialização, além de outros aspectos de gênero, raça e classe. Pode-se afirmar aqui que a cultura urbana, sob a ideia de civilidade-superioridade-progresso, adentra a construção da cultura escolar, que além da cidade ser o lócus de privilégio das ações, ela também produz e difunde ideologias dominantes que inferiorizam o campo, pois "trabalha teórica e retoricamente com um conjunto de dicotomias, tais como bárbaro e civilizado, arcaico e moderno, velho e novo, rural e urbano, entre muitas outras". (FARIA FILHO, 2005, p. 31). A missão posta pela educação e o espaço urbano passa a basear a modernidade e o progresso, e, na República isso se reitera com grande força, pois a noção de civilidade, cidadania, urbanidade, modernidade.

À exemplo, Musial (2011) ao pesquisar sobre a configuração da educação rural em Minas Gerais entre 1892 e 1899, identifica o aparecimento pela primeira vez da denominação escola rural na Lei Estadual no 41 de 1892 (que classifica os cursos oferecidos pelo governo em rural, distrital e urbano), o que trouxe visibilidade ao tema, mas que efetivamente privilegiou melhorias em escolas distritais e urbanas. Além disso, o autor identifica que nesse período as representações sociais sobre a educação rural eram marcadas pela rusticidade, ineficácia de professores, infrequência dos alunos e desinteresse dos pais, que foram usadas como justificativas para supressão das escolas rurais ao longo dos anos seguintes. Ou seja, houve uma distinção que produziu e justificou os processos de exclusão. Outro exemplo que afirma esse processo de negligenciamento da educação rural e maiores esforços para pensar a educação e a vida urbana é o fato de, também, em terras mineiras, em 1908, a escolas infantis terem como disciplina básica a denominada Urbanidade, assim, há elementos para a construção de uma cultura escolar que passa a produzir as dicotomias entre campo e cidade. (FARIA FILHO, 2005).

Outro exemplo interessante é afirmado em Pinto (2012), ao discorrer sobre as tensões na constituição da Escola Primária em Goiás na Primeira República. A autora conclui que as ações focalizavam estratégias reformistas dando ênfase no urbano, em uma sociedade goiana ainda rural, o que desencadeou os fracassos dos movimentos de reforma. Essas reformas tinham como referência escolas urbanas da capital paulista, que se pautavam no desejo de modernidade, tendo a educação a função moralizadora, moderna, progressista e, sobretudo, civilizatória.

Nessa dimensão infere-se a força de como a urbanidade perpassa as normas e práticas do espaço escolar, a partir da finalidade civilizatória que busca transmitir conhecimento e incorporar comportamentos de cidadãos urbanos. Atesta-se que há a difusão, a partir da escola, de "modos de pensar e de agir largamente difundidos no interior de nossas sociedades, modos que não concebem a aquisição de conhecimentos e de habilidades senão por intermédio de processos formais de escolarização" (JULIA, 2001, p.11), que marca a cultura escolar dessas instituições. Essas normas e práticas até certos momentos históricos foram centralmente teológicas e a partir de movimentos da ilustração se tornaram egológicos 
(secundarizando o teológico, que jamais deixa de existir), assim, essas práticas e normas escolares são marcadas pelas finalidades sociais, que a própria escola produz, tomando como alicerce a dominação colonial/moderna, onde as culturas dominantes urbanas subjugam as produções de existência rurais. $A$ referência para pensar a escola é urbanocentrada, e dessa maneira, eurocêntrica, dicotômica, sob o viés das colonialidades dos povos do campo.

A escolarização se torna o ponto fundamental para o progresso da República Educadora, há então uma expansão da escolarização, devido às transformações sociais e econômicas, para as classes médias e pobres urbanas. Porém, até a década de 1930, a escolarização no território rural "continuou descontínuo e desordenado, como sempre fora" (LEITE, 1999, p.28). As experiências rurais continuavam marginalizadas, sendo o urbano o principal ponto de investimento, ações políticas, administração e desenvolvimento, sob a ideia moderna de projeto societário urbano-industrial. Nessa lógica, a visão eurocêntrica/moderna ainda continua a ser exercida na ordem geopolítica brasileira, o campo é colocado como lugar menor, que constrói “o "outro" mediante uma lógica binária que reprimia as diferenças" (CASTRO-GÓMEZ, 2005, p. 80), ou seja, o Estado cria os critérios de civilidade, para homogeneização dos sujeitos, negando e invisibilizando as diferenças em suas ações em prol do projeto de modernidade/urbano/capitalista.

Por volta de 1910/20 acontece um movimento latente de êxodo rural, pois, sem condições dignas para a vida no campo, e sob a égide da cidade como lugar do progresso, a imigração se configura como alternativa. As cidades passam a serem tomadas pela ruralidade, os sujeitos do campo passam a ser vistos, e passam a configurar problemas sociais nos centros urbanos. Os bárbaros vieram para as cidades, $e$ agora? Como lidar com a desestabilização da ordem citadina? Com eles vêm seus modos de vida, de comportamento, cultura e organização, e a própria desconfiguração do espaço agroexportador, que era a base para o processo urbano. A imigração é uma ameaça epistemológica, comportamental, econômica e cultural. A partir do momento que essas diferenças não são mais passíveis de ser invisibilizadas, pois a questão é latente na cidade, passa-se a pensar na educação em território rural, como estratégias para a fixação do homem no campo. (LEITE, 1999).

No século XX a escolarização no campo foi usada "ora como instrumento adequado para fixar o homem no campo [...], ora como instrumento ideal para transformar mentalidades arcaicas e rurais em mentalidade citadinas" (FREITAS; BICCAS, 2009, p.27). Nessa acepção, entende-se que a educação sempre teve elementos pautados na transformação das mentalidades do campo (a partir do ideal de modernidade), e assim, inferiorizando seus processos, mesmo quando era para fixar esses sujeitos no campo ou para domesticar na constituição de mão de obra.

O Ruralismo Pedagógico foi uma experiência do começo do século XX que se deu com a emergência da fixação do homem no campo, um movimento que passou a olhar para o campo a partir de suas especificidades, que além de conter o problema da imigração, também se calcava sob a égide da compreensão das especificidades do campo e sua valorização (LEITE, 1999). Buscam-se então, estratégias para fixar os camponeses desta forma, mesmo que essa perspectiva estivesse olhando para a especificidade, ela não busca romper lógicas de dominação e alienação desses sujeitos, no sentido de não pensar uma educação para dar possibilidades de vida, direcionadas pelos desejos dos camponeses (de ficar ou não no campo), mas como alternativa de fixar, limitando a autonomia dos sujeitos - caracterizando uma violência colonial. Porém, logo essa ideia foi posta de lado, e a partir de 1930 a tônica para educação no território rural passou a ser da Educação Rural.

A Educação Rural estava relacionada com o desenvolvimento econômico urbano-industrial, se firmou no começo dos anos 1930 e se potencializou durante o processo de industrialização dos anos 1950, 1960 e 1970, associada, contraditoriamente, com a Reforma Agrária, no intuito do Estado fornecer escolarização e formação técnico-profissional para formar mão de obra qualificada para atuar no processo de industrialização e modernização do campo, para que assim o desenvolvimento do capitalismo no campo pudesse ocorrer de forma mais intensa e rápida. (RIBEIRO, 2012).

Assim se compreende que o sistema capitalista tenha incorporado[...], a Reforma Agrária, porém, associada aos interesses de classe, visando a modernização do campo, pela introdução de máquinas, insumos agrícolas, métodos de administração rural etc.; e isso requeria alguma forma de escolarização, o que explica a relação entre educação rural, o desenvolvimento econômico e a Reforma Agrária”. (RIBEIRO, 2012, p. 295, grifos nosso). 
Essa concepção de educação estava vinculada aos interesses da elite e oligarquias agrárias, sob um projeto que tendia a intensificar a submissão do trabalho ao capital, se opondo à formulação da educação como processo de libertação das relações de opressão dos camponeses. Desta maneira, a Educação Rural está a serviço do mercado e da economia, e, assim, da própria colonialidade dos sujeitos do campo, oferecendo uma educação unicamente nesses moldes, anulando suas condições de existência, suas lutas e seus modos de vida, conferindo a estes funções e educação alienadoras para gerar de mão de obra para sujeição ao capitalismo.

Calazans, Castro e Silva (1981) apontam que a Educação Rural lançou mão de diversos programas, projetos e ações direcionadas para o campesinato, porém, sempre teve uma importância quase irrelevante para o setor público. Caracterizando assim, as contradições dessas ações, que ao oferecer uma educação alienada, ainda a fazia de maneira desestruturada. Esses programas se estruturavam como um pacote fechado, sem qualquer participação dos sujeitos do campo nas suas elaborações, sendo utilizadas como práticas para desviar a atenção sobre as reais necessidades do campo, que os Movimentos Sociais do Campo reivindicavam. Pois, assimilaram a Reforma Agrária sob o interesse da industrialização/modernidade/colonialidade dos territórios, usando a escolarização desqualificada para domesticar e limitar as possibilidades de vida desses sujeitos.

Além disso, a Educação Rural que é a forma escolar que perpassa várias décadas rurais, está sob a tônica do processo de transplantar uma educação urbana para a realidade rural, sem nenhum critério, há um transplante de uma escola urbanocentrada, que se constrói a partir das ideias de colonialidade/modernidade que geram a dicotomia entre rural e urbano. Deste modo, há uma dupla violência colonial exercida pelo Estado: a de levar e impor uma educação que não dialoga com as necessidades camponesas e sim com o processo de expansão capitalista; e de impor uma educação que está baseada na inferiorização epistêmica, linguística, existencial, cultural, social e política desses povos. Nesse momento o capitalismo toma a centralidade (que já vinha conquistando) na estrutura educacional, e específica dos sujeitos do campo, replicando a estrutura de dominação e colonialidade do poder (QUIJANO, 2005). Já que as relações de trabalho escravo e servidão tinham acabado, e o trabalho assalariado toma a centralidade, a escola passa a ser o lócus para a formação de mão de obra. Além disso, esse movimento deixa latente principalmente a Colonialidade da Natureza, com o processo de industrialização e modernização do campo, onde esse território se torna para o capitalismo lugar a ser explorado, e os camponeses, vidas a serem expropriadas pelos latifundiários e pelo agronegócio.

Destarte, estende-se que mesmo quando essa escola é no território rural, ela é pensada sob a égide urbanocentrado (cultural, política, organização, econômica e social urbana), e passa a reproduzir e produzir-se sob o viés de uma organização que é da experiência urbana. Estando envolta de toda a arbitrariedade construída a partir da colonialidade/modernidade/eurocêntrica, cria-se a ideia de que o rural é a extensão do urbano (pois ele não tem potencial de produzir formas de saber, de ser, de produzir, de cultura), assim a escola urbanocentrada pode estar naquele lugar sem nenhum problema, há sempre a incivilidade e inferiorização da ruralidade. Pois, não há a compreensão que apesar do rural ser integrado ao urbano (WANDERLEY, 2001), e vice e versa, esses são espaços que possuem especificidades que não se pautam em dicotomias de inferioridade-superioridade, mas na própria interação objetiva e subjetiva com o meio que produz relações de existências e experiências diferentes. Segundo Silva, Torres e Lemos (2012, p. 424), “o ensino ofertado na área rural sob os moldes da educação urbana apresentavase distante e desconectado da vida cotidiana, negando os saberes e as culturas desses povos e toda forma de conhecimento que não fosse propedêutica", urbano e colonizador.

Até os dias atuais a educação nos territórios do campo enfrenta e é atingida pelos paradigmas da Educação Rural, que dialogam com interesses dominantes e do agronegócio, como ações reacionárias de bloqueio de repasses financeiros e com a insistência de reerguer modelos voltados para concepções da Educação Rural (RIBEIRO, 2012). Há uma grande ofensiva por parte do Estado Neoliberal, que vem com processos de desconstrução das escolas nos territórios rurais, com políticas de fechamento de escolas, nucleação escolar e transporte dos alunos para as escolas da cidade, negando a estes qualquer vinculação com suas raízes.

Silva, Torres e Lemos (2012) sinalizam que nesse sentido a educação escolar ofertada ao campo brasileiro tem um caráter desumanizador, urbano e instrumental. Desta forma, historicamente, a Educação no Brasil se coloca dentro da Colonialidade da educação brasileira, em movimentos de 
subalternização dos povos do campo (e dos demais povos indígenas e negros), sempre baseado e construindo representações sociais que inferiorizam a existência desses sujeitos e suas experiências enquanto fonte de produção epistemológica, social e cultural para se pensar os processos educativos, formas de lidar com a realidade nacional. Nessa sequência, a construção da educação no Brasil se consolida a partir da colonialidade do poder, saber, ser e dos territórios (natureza) dos povos subalternizados, para a própria construção da educação urbana, que centralmente olhava para a consolidação da elite. Essas relações de colonialidade reverberam fortemente nos povos do campo, assim, estes por muitas décadas não foram nem pensandos enquanto sujeitos passíveis de ter acesso à educação escolar, e quando foram pensados, os aspectos da colonialidade perpassam a forma escolar oferecida para eles - Colonialidade da Educaşão.

Por conseguinte, há diversas relações de dominação e inferiorização desses sujeitos, que não se dão a partir da essencialidade, mas a partir dos percursos históricos de dominação colonial, da colonialidade e dos próprios processos educacionais institucionais. Mas esses movimentos também estão envoltos de práticas de resistência e insurgência, como o Movimento de Educação do Campo.

\section{DECOLONIALIDADE - Educação do campo ${ }^{7}$ como movimento de resistência}

Nessas reminiscências apresentadas até aqui, mesmo que de forma sintética, discorre-se sobre os aspetos que envolveram a colonialidade da Educaşão, baseada no colonialismo e na colonialidade dos povos do campo, para assim refletir historicamente sobre os aspectos que envolvem e estruturam a educação camponesa brasileira. Porém, não se pode deixar de pontuar, que dentro dessas Colonialidades, também existiram e existem movimentos de resistência, pois “a Colonialidade, em seus variados eixos, não conseguiu se estabelecer completamente nas relações políticas, sociais e epistêmicas nos territórios colonizados, tanto no período colonial, como no contexto neoliberal (neocolonial) contemporâneo" (SILVA; SILVA, 2014, p.167, grifos dos autores). Há o que aqui pontuamos como projetos decoloniais e resistência - Decolonialidade.

Os projetos decoloniais são as reações dos povos subalternizados ao projeto societário colônia/moderno/urbano, que desde a colonização vem reagindo às violências. "La decolonialidad es, entonces, la energía que no se deja manejar por la lógica de la colonialidad, ni se cree los cuentos de hadas de la retórica de la modernidad" (MIGNOLO, 2007, p.27). A Decolonialidade da educação se coloca no ato de se pensar, e, além disso, em uma práxis com base na insurgência, na criação, na busca de alternativas, para se construir novos percursos sociais, políticos, epistêmicos que fujam da dominação da colonialidade/neocolonial/neoliberal/capitalista/urbana. E, sobretudo, na busca pela construção de um percurso educativo que não se baseia em dicotômicas, dominação, racismo, machismo, mas que consiga realizar movimentos interculturais. "DEcolonizar na educação é construir outras pedagogias além da hegemônica" (OLIVEIRA, s/a, p.03), olhando para os Movimentos Sociais insurgentes que anunciam formas de educação alternativas.

Dentro disso, nos processos educacionais sempre houve práticas Decoloniais dos grupos subalternizados; esses sujeitos vêm fazendo giros decoloniais desde o processo de colonização, mesmo sendo sufocados existencialmente, realizam diversas práticas de luta e resistência. Para Bernardino-Costa e Grosfoguel (2016, p. 17) a decolonialidade "consiste [...] numa prática de oposição e intervenção, que surgiu no momento em que o primeiro sujeito colonial do sistema mundo moderno/colonial reagiu contra os desígnios imperiais". Então, essas práticas podem ser vistas nas experiências dos sujeitos subalternizados pela modernidade/colonialidade desde a colonização da América, seja nas resistências indígenas, nas expressões culturais dos negros escravizados, nos movimentos de resistência e luta pela terra no campo.

$\mathrm{Na}$ educação, podem-se perceber as resistências decoloniais nos processos educativos institucionais e não instrucionais, por exemplo: dos negros no período imperial, como ações e estratégias de alfabetização e educação de seus povos; a resistência dos povos indígenas em não aceitarem processos educativos coloniais de aculturação; as lutas das mulheres para a inserção na educação escolar (GONDRA; SCHUELER, 2008); a insurgência da Educação Popular de Paulo Freire, que criticou as desconecções da educação com a realidade nacional e pensou em alternativas para uma educação libertadora, crítica e problematizadora das relações de dominação, contribuindo para processos de 
resistências e práticas educativas e políticas (FREITAS; BICCAS, 2009; PALUDO, 2006). Além disso, a luta pela terra e pela educação articulada pelos Movimentos Sociais do Campo, protagonizada pelo MST (Movimento de Trabalhadores Sem Terra) que desde os anos 1980/1990, período de redemocratização (saída do regime militar - que reprimiu fortemente esses movimentos no Brasil), vem resistindo à Educação Rural e as políticas educacionais neoliberais, e lutando pela Educação do Campo (CALDART, 2012). Essas são algumas práticas educacionais decoloniais, sendo a Educação do Campo uma das ações decoloniais nos territórios nacionais.

Assim, assume-se aqui a Educação do Campo enquanto movimento insurgente que, além de enunciar epistemologias alternativas, tem suas origens nos movimentos decoloniais, fundamental nos Movimentos Sociais do Campo e nos percursos da Educação Popular. Mas também tem suas raízes nas lutas dos povos negros e indígenas que historicamente vêm realizando práticas de resistências políticas, epistêmicas, culturais e educacionais. Destacam-se nesse trajeto os Movimentos Sociais do Campo, por historicamente estes serem os articuladores das ações de resistência e enfretamento das opressões do campo. Pois, "ao tomarem a terra como elemento central de suas lutas, articulam outras dimensões constitutivas como a educação, o trabalho e a cultura nas resistências ao modelo colonial/capitalista/urbanocêntrico" (SILVA et al, 2012, p.17). Desta maneira, o protagonismo desse movimento é central na constituição desse percurso, a partir das suas experiências educativas, movimento de educação institucional e não-institucional, luta pela identidade, epistemologia, cultura e terra (existência material e subjetiva), a pela própria luta por políticas públicas (obteve-se diversos avanços legais ${ }^{8}$ ), tensionando o Estado neoliberal/colonial pela ampliação dos direitos dos povos. Farias e Faleiro (2018, p.358) afirmam a partir de uma análise história, a Educação do Campo "enquanto movimento potente, associado a um projeto societário, epistemológico, político, cultural e educacional contra-hegemônico, podemos colocá-lo como um projeto de Desobediência Político-epistemológico".

O Movimento de Educação do Campo, enquanto movimento sociopolítico brasileiro (CALDART, 2012), vem se constituindo a partir dos Movimentos Sociais do Campo e com a articulação de outros órgãos da sociedade, como as universidades, para se pensar formas de educação que sejam DO campo, ou seja, que tenha os povos do campo como sujeitos protagonistas desse processo, que valorize sua cultura, modos de produção, superando olhares dicotômicos e estereotipados que as colonialidades impõem. Não busca fechar-se em si mesmo, mas parte da necessidade histórica em colocar o campo como lugar visível, produtor de experiências essenciais para a constituição da humanidade, e assim, busca articular as outras culturas de maneira a afirmar os valores do campo. A "Educação do Campo se sustenta em pilares pedagógicos e princípios políticos firmados no respeito e no diálogo entre as culturas na direção da construção de uma sociedade outra" (SILVA; TORRES; LEMOS, 2012, p.432, grifos dos autores). Quijano (2005, p. 139) sinaliza que "é tempo de aprendermos a nos libertar do espelho eurocêntrico onde nossa imagem é sempre, necessariamente, distorcida. É tempo, enfim, de deixar de ser o que não somos". Desta forma, sinaliza-se a Educação do Campo como um dos movimentos que apontam para essa construção de uma educação e sociedade brasileiras, a partir realmente do que os povos são, superando representações sociais pautadas na inferiorização, se articulando com os demais movimentos que estão nessa perspectiva, como o Movimento Negro, Feminista, LGBTT' ${ }^{9}$, das periferias urbanas, entre outros.

\section{CONSIDERAÇÕES FINAIS}

Atualmente as Escolas do Campo ainda possuem grandes dificuldades de se estabilizarem sobre o paradigma da Educação do Campo, pois o paradigma da Educação Rural e das colonialidades do poder, saber, ser e da natureza ainda permanecem embarreirando os avanços dos Movimentos Sociais do Campo na educação.

Logo, são necessários a vigilância e o fortalecimento de práticas, políticas, conhecimentos e experiências insurgentes que tenham o potencial de desenvolver e enunciar novas epistemologias, ontologias e formas de educação institucional e não-institucional, para não permitir retrocessos. E, sobretudo, lutar para que os povos subalternos sejam protagonistas dos processos que dizem respeito a sua própria existência, onde projetos societários e educacionais se pautem igualmente nas enunciações dos grupos sociais que 
constituem o Brasil e o mundo, superando assim a modernidade, o eurocentrismo e as dicotomias entre urbano-rural, criando movimentos de interculturalidade.

Desta maneira, a luta se dá a partir da ideia de que os sujeitos do campo possam consolidar a Educação do Campo (e tudo que está associado a ela, como o acesso à terra e a soberania alimentar, entre outras coisas), rompendo as Colonialidades historicamente construídas e latentes na contemporaneidade, que perpassam as formas educacionais do nosso país.

O potencial de enunciação aberto pela Educação do Campo, enquanto movimento e possiblidade de pensar alternativas para a educação escolar do campo, não perpassa o pensar somente o campo, mas possibilita pensar sobre uns projetos decolonais de Brasil. Pois, é necessário frisar que os espaços urbanosrurais estão interligados, e que os processos de mudanças sociais que ocorrem em um desses territórios modificam também as estruturas do outro território, assim, é necessário compreender estes enquanto espaços interligados, onde o campo não deve e nem pode ser invisibilizado ou inferiorizado, pois o desenvolvimento nacional depende intensamente desses movimentos do campo, bem como depende dos movimentos urbanos. Para assim se construir um país sob a tônica da justiça social, na superação das relações de opressão.

\section{REFERÊNCIAS}

ASSIS, W. F. T. Do colonialismo à colonialidade: expropriação territorial na periferia do capitalismo. CADERNO CRH, Salvador, v. 27, n. 72, p. 613-627, set.- dez. 2014.

BALLESTRIN, L. América Latina e o giro decolonial. Revista Brasileira de Ciência Política, $\mathrm{n}^{\circ} 11$. Brasília, mai. - ago. 2013, p. 89-117.

BERNARDINO-COSTA, J.; GROSFOGUEL, R. Decolonialidade e perspectiva negra. Revista Sociedade e Estado, Brasília, v.31, n.1, p. 15-24, jan.- abr. 2016.

BOTO, C. A liturgia da escola moderna: saberes, valores, atitudes e exemplos. Revista História da Educação, v. 18, n. 44, set. - dez., 2014.

BOTO, C. O Curso de Medicina da universidade pombalina: ciência e pedagogia no Iluminismo português. In: FONSECA, T. N. de L. (Org). As Reformas Pombalinas no Brasil. Belo Horizonte: Mazza Edições, 2011.

CALAZANS, M. J. C.; CASTRO, L. F. M. de; SILVA, H. R. S. Questões e Contradições da Educação Rural no Brasil. In: WERTHEIN, J; BORDENAVE, J. D. (Orgs.). Educação Rural no Terceiro Mundo: Experiências e Novas Alternativas. Rio de Janeiro: Paz e Terra, 1981.

CALDART, R. S. Educação do Campo. In: CALDART, Roseli et al. (Orgs.). Dicionário da Educação do Campo. Rio de Janeiro: Escola Politécnica de Saúde Joaquim Venâncio, Expressão Popular, 2012.

CASTRO-GÓMEZ, S. e GROSFOGUEL, R. Prólogo. Giro decolonial, teoría crítica y pensamiento heterárquico In.: CASTRO-GÓMEZ , S. e GROSFOGUEL, R. (Org.). E1 giro decolonial: reflexiones para una diversidad epistémica más allá del capitalismo global. - Bogotá: Siglo del Hombre Editores; Universidad Central, Instituto de Estudios Sociales Contemporáneos y Pontificia Universidad Javeriana, Instituto Pensar, 2007.

CASTRO-GÓMEZ, S. Ciências sociais, violência epistêmica e o problema da "invenção do outro". In.: LANDER, E. (Org.). A colonialidade do saber: eurocentrismo e ciências sociais. Perspectivas latinoamericanas. Colección Sur Sur, CLACSO, Ciudad Autónoma de Buenos Aires, Argentina, set. 2005.

CRUZ, T. A. Os processos de lutas e resistências dos povos indígenas do Brasil. Revista SURES, n. 9, p. 145-163, 2017. 
DUSSEL, E. Europa, modernidade e eurocentrismo. In.: LANDER, Edgardo (Org.). A colonialidade do saber: eurocentrismo e ciências sociais. Perspectivas latino-americanas. Colección Sur Sur, CLACSO, Ciudad Autónoma de Buenos Aires, Argentina, set. 2005.

FARIAS, M, N.; FALEIRO, W. Movimento de educação do campo enquanto fenômeno decolonial: afirmando percursos de desobediência político-epistemológica. Revista Educação e Cultura Contemporânea, v. 15, n. 39, p.357-374, 2018. DOI: 10.5935/2238-1279.20180038.

FARIA FILHO, L. M. de. Cultura escolar e cultura urbana: perspectivas de pesquisa em história da educação. In.: XAVIER, L. N. et al. Escola, Culturas e Saberes. Rio de Janeiro: Editora FGV, 2005.

FONSECA, T. N. de L. e. Iluminismo e Reforma: civilidade, educação moral e práticas culturais dos professores régios. In: DORÉ, Andréa; SANTOS, Antonio C. (Orgs). A Temas Setecentistas: governos e populações no Império Português. Curitiba: UFPR/Fundação Araucária, 2009.

FREIRE, P. Educação como prática da liberdade. 39ºd. São Paulo: Paz e Terra, 2016.

FREIRE, P. Pedagogia do Oprimido. $17^{\circ}$ ed. Rio de Janeiro: Paz e Terra, 1987.

FREITAS, M. C. de; BICCAS, M. de S. História social da educação no Brasil (1926-1996). São Paulo: Cortez, 2009.

GONDRA, J. G.; SCHUELER, A. Educação, poder e sociedade no império brasileiro. São Paulo: Cortez Editora, 2008.

GONZÁLEZ STEPHAN, B. Modernización y disciplinamiento. La formación del ciudadano: del espacio público y privado. In.: GONZÁLEZ STEPHAN, B et al. (Org.). Esplendores y miserias del siglo XIX. Cultura y sociedad en América Latina. Caracas: Monte Ávila Editores, 1995.

GROSFOGUEL, R. Descolonizando los paradigmas de la economia política: transmodernidad, pensamiento fronterizo y colonialidad global. 2016. Disponível em: < http://www.manuelugarte.org/modulos/biblioteca/g/ramon_grosfoguel_descolonizando_paradigmas _economia_transmodernidad.pdf>. Acesso em: 05 jan. 2016.

GROSFOGUEL, R. Para Descolonizar os Estudos de Economia Política e os Estudos Pós-coloniais: transmodernidade, pensamento de fronteira e colonialidade global. In.: SANTOS, B. de S.; MENESES, M. P. (Org.). Epistemologias do Sul. Coimbra: Almedina, 2009.

JULIA, D. A cultura escolar como objeto histórico. Revista Brasileira de História da Educação, n. 1, p. 9-43, jan. - jun. 2001.

LANDER, E. Apresentação. In.: LANDER, Edgardo (Org.). A colonialidade do saber: eurocentrismo e ciências sociais. Perspectivas latino-americanas. Colección Sur Sur, CLACSO, Ciudad Autónoma de Buenos Aires, Argentina, 2005.

LEITE, S. C. Escola rural: urbanização e políticas educacionais. São Paulo: Cortez, 1999. - (Coleção questões da nossa época: v. 70).

MALDONADO-TORRES, N. A Topologia do Ser e a Geopolítica do Conhecimento: modernidade, império e colonialidade. In: SANTOS, B. de S.; MENESES, M. P. (Orgs.). Epistemologias do Sul. Coimbra: Almedina, 2009.

MALDONADO-TORRES, N. Sobre la colonialidad del ser: contribuciones al desarrollo de un concepto. In.: CASTRO-GÓMEZ, S. e GROSFOGUEL, R. (Org.). Prólogo. Giro decolonial, teoría crítica y pensamiento heterárquico. El giro decolonial: reflexiones para una diversidad epistémica más allá del 
capitalismo global. - Bogotá: Siglo del Hombre Editores; Universidad Central, Instituto de Estudios Sociales Contemporáneos y Pontifi cia Universidad Javeriana, Instituto Pensar, 2007.

MIGNOLO, W. D. A colonialidade de cabo a rabo: o hemisfério ocidental no horizonte conceitual da modernidade. In.: LANDER, E. (Org.). A colonialidade do saber: eurocentrismo e ciências sociais. Perspectivas latino-americanas. Colección Sur Sur, CLACSO, Ciudad Autónoma de Buenos Aires, Argentina. setembro 2005

MIGNOLO, W. D. El pensamiento decolonial: desprendimiento y apertura. Un manifiesto. In: CASTRO-GÓMEZ , S.; GROSFOGUEL, R. (Org.). El giro decolonial: reflexiones para una diversidad epistémica más allá del capitalismo global. - Bogotá: Siglo del Hombre Editores; Universidad Central, Instituto de Estudios Sociales Contemporáneos y Pontifi cia Universidad Javeriana, Instituto Pensar, 2007.

MIGNOLO, W. Geopolítica de la sensibilidad y del conocimiento - sobre (de)colonialidad, pensamiento fronterizo y desobediencia epistémica. Traducción de Marcelo Expósito, Eipcp. 2011. DISPONÍVEL: < http://eipcp.net/transversal/0112/mignolo/ES>. Acesso em: 10 jan. 2016.

MUSIAL, G. B. da S. A emergência da escola rural em Minas Gerais (1892-1899): quando a distinção possibilita a exclusão. 258f. Tese (Doutorado em Educação) - Universidade Federal de Minas Gerais UFMG, 2011.

OLIVEIRA, L. F. de. O que é uma educação decolonial?. s/a. Disponível em: <https://www.academia.edu/23089659/O_QUE_\%C3\%89_UMA_EDUCA\%C3\%87\%C3\%83O_D ECOLONIAL> Acesso em: 10 jan. 2017.

PAIVA, J. M. A educação jesuítica no Brasil Colônia. In: LOPES, E. M. T., FARIA FILHO, L. M.; VEIGA, C. G. (Orgs.). 500 anos de educação no Brasil. Belo Horizonte: Autêntica, 2003.

PALUDO, C. Educação Popular em busca de alternativas. Uma leitura desde o campo democrático e popular. Porto Alegre: Tomo Editorial, CAMP, 2006.

PINTO, R. N. Escola Primária em Goiás na Primeira República: tensões e distensões de um "jogo de empurra". In: ARAÚJO, J. C. S.; SOUZA, R. F. de; PINTO, R-M. N. (Orgs.). Escola primária na Primeira República (1889-1930): subsídios para uma história comparada. Araraquara, SP. Junqueira \& Marin, 2012.

PORTO-GONÇALVES , C. W. Apresentação da edição em português. In.: LANDER, E. (Org.). A colonialidade do saber: eurocentrismo e ciências sociais. Perspectivas latino americanas. Colección Sur Sur, CLACSO, Ciudad Autónoma de Buenos Aires, Argentina, set. 2005.

QUIJANO, A. Colonialidade do Poder e Classificação Social. In.: SANTOS, Boaventura de Sousa e MENESES, Maria Paula (Org.). Epistemologias do Sul. Coimbra: Almedina, 2009.

QUIJANO, A. Colonialidad y modernidad-racionalidad. In.: PALERMO, Z.; QUINTERO, P. Anibal Quijano. Textos de fundación. Colección El despendimiento. Buenos Aires - Argentina: Ediciones del Signo. 2014.

QUIJANO, A. Colonialidade do poder, Eurocentrismo e América Latina. In.: LANDER, E. (Org.). A colonialidade do saber: eurocentrismo e ciências sociais. Perspectivas latino-americanas. Colección Sur Sur, CLACSO, Ciudad Autónoma de Buenos Aires, Argentina, set. 2005.

RIBEIRO, M. Educação Rural. In: CALDART, Roseli et al. (Orgs.). Dicionário da Educação do Campo. Rio de Janeiro: Escola Politécnica de Saúde Joaquim Venâncio, Expressão Popular, 2012. 
SILVA, F. da; TORRES, D. X.; LEMOS, G. T. Educação do campo: a luta dos movimentos sociais campesinos por uma educação escolar específica e diferenciada. Revista Pedagógica UNOCHAPECÓ, Chapeco, v.1, n. 28, p. 409-438, jan.- jun. 2012.

SILVA, F. G. P. da; SILVA, J. F. da. A crítica decolonial das epistemologias do sul e o contexto de constituição das coleções didáticas do pnld-campo/2013. REALIS, v.4, n. 02, jul./dez. 2014.

SILVA, J. F. da et al. Paradigmas da educação do campo: um olhar a partir dos estudos pós-coloniais latino-americanos. Revista Reflexão e Ação, Santa Cruz do Sul, v. 22, n.2, p. 09-38, jul./dez. 2014.

WALSH, C. Interculturalidad, plurinacionalidad y decolonialidad: las insurgencias político-epistémicas de refundar el Estado. Tabula Rasa. Bogotá - Colombia, nº.9: 131-152, julio-diciembre 2008.

WANDERLEY, M. de N. B. A ruralidade no Brasil moderno. Por um pacto social pelo desenvolvimento rural. In.: GIARRACCA, N. (Org.). ¿Una nueva ruralidad en América Latina?. CLACSO, Consejo Latinoamericano de Ciencias Sociales, Ciudad Autónoma de Buenos Aires, Argentina. 2001.

Submetido: 10/11/2018

Aprovado: 19/02/2020

Contato:

Magno Nunes Farias

Centro de Educação e Ciências Humanas |CECH| UFSCar

Rodovia Washington Luis, km 235, Caixa Postal 676.

São Carlos | SP | Brasil

CEP 13565-905

\footnotetext{
${ }^{1}$ Entende-se que a geografia (lugar, território a qual pertence) e a corporalidade (marcas do corpo - gênero, sexo, raça, sexualidade) são critérios decisivos nas relações de poder. Hegemonicamente as relações de poder (re) produziram e ainda (re) produzem a supremacia geográfica (eurocêntrica) e corpórea (homem, sexo masculino, branco, heterossexual), que constituem a dominação colonial (QUIJANO, 2009). Porém, nesse trabalho a geo-corpo-política se dá a partir da decolonialidade, centrando-se em enunciações geograficamente e corporalmente marginalizados, ou seja, produções latino-americanas, nãobrancas e que busca desestabilizar padrões de gênero e a heteronormatividade.

2 "A globalização em curso é, em primeiro lugar, a culminação de um processo que começou com a constituição da América e do capitalismo colonial/moderno e eurocentrado como um novo padrão de poder mundial” (QUIJANO, 2005, p. 117). E atualmente se mobiliza centralmente a parir da globalização neoliberal.

3 "Seja do ponto de vista conceitual, seja do ponto de vista da experiência histórica o tema cidadania remete constantemente à cidade, urbanidade e civilidade" (FARIA FILHO, 2005, p.32, grifos do autor).

4 “[...] o capitalismo como sistema de relações de produção, isto é, a heterogênea engrenagem de todas as formas de controle do trabalho e de seus produtos sob o domínio do capital, no que dali em diante consistiu a economia mundial e seu mercado, constituiu-se na história apenas com a emergência da América” (QUIJANO, 2005, p.126).

5 "Para ser breve, poder-se-ia descrever a cultura escolar como um conjunto de normas que definem conhecimentos a ensinar e condutas a inculcar, e um conjunto de práticas que permitem a transmissão desses conhecimentos e a incorporação desses comportamentos; normas e práticas coordenadas a finalidades que podem variar segundo as épocas (finalidades religiosas, sociopolíticas ou simplesmente de socialização)" (JULIA, 2001, p.10).

${ }^{6}$ Utiliza-se os eventos político-administrativos para se compreender a constituição da sociedade brasileira em três formas: Colônia (1500-1822), Império (1822-1889) e Republica (1889 - atualmente). Entende-se que esses períodos são formas importantes para entender a constituição da educação escolar nesse território. Porém, também é importante sinalizar suas insuficiências para explicar acontecimentos tão complexos, sendo necessário perceber os eventos que fogem dessa normativa (GONDRA; SCHUELER, 2008).

${ }^{7}$ É importante frisar que a Educação do Campo é um Movimento que tem por finalidade superar a Educação Rural, por isso é fundamental a consolidação da sua nomenclatura em todos os espaços legislativos e de discussão. O termo é fundamental
} 
para a afirmação do projeto político que contempla uma perspectiva pedagógica e educacional contra-hegemônica, com o objetivo emancipador das populações do campo, compreendendo suas lutas, culturas e modos de vida.

${ }^{8}$ Constituição Federal de 1988; Lei de Diretrizes e Bases da Educação Nacional - LDB n. 9394/96 (onde aparece a educação para povos do campo enquanto especificidade, pela primeira vez); Diretrizes Operacionais para a Educação Básica nas Escolas do Campo (Resolução CNE/CEB n. 1/2002); Diretrizes Complementares, Normas e Princípios para o Desenvolvimento de Políticas Públicas de Atendimento da Educação Básica do Campo (Resolução CNE/CEB n. 2/2008); Política de Educação do Campo e o Programa Nacional de Educação na Reforma Agrária (PRONERA) (Decreto n. 7.352/2010) (SILVA; TORRES; LEMOS, 2012); entre outros.

${ }^{9}$ Lésbicas, Gays, Bissexuais, Travestis e Transexuais - LGBTT. 